\title{
Job Satisfaction Survey: A Confirmatory Factorial Analysis Based on Vocational Colleges Teachers Sample
}

\section{Mohamad Zaid Mustafa ${ }^{1^{*}}$, Yahya Buntat ${ }^{2}$, Rosnee Ahad ${ }^{3}$, Abdul Rasid Abdul Razzaq $^{4}$ and Norzella Bokhari ${ }^{5}$}

1,3, 4, ${ }^{5}$ Faculty of Technical and Vocational Education, Universiti Tun Hussein Onn Malaysia, 86400 Parit Raja, Batu Pahat, Johor. MALAYSIA

${ }^{2}$ School of Education, Faculty of Social Sciences and Humanities, Universiti Teknologi Malaysia, 81310 Skudai, Johor, MALAYSIA

DOI: https://doi.org/10.30880/jtet.2019.11.03.017

Received $19^{\text {th }}$ August 2018; Accepted 27 $7^{\text {th }}$ September 2019; Available online $30^{\text {th }}$ September 2019

\begin{abstract}
This study was carried out to verify the measurement model of the construct of job satisfaction among technical teachers in Technical Vocational College Ministry of Education. A study involving 493 samples from 25 vocational colleges and comprising technical teachers in electrical and electronics engineering, civil engineering and mechanical engineering. The Structural Equation Modelling (SEM) approach with AMOS 20 software has been applied in this study. The original item was the adaptation of the Job Satisfaction Survey (JSS) questionnaire developed by Spector (1997), there were 32 items, after exploratory factor analysis was carried out 32 original items had decreased to 22 items, sub construct was also changed from 8 sub constructs to 4 sub construct only. To ensure that the job satisfaction measurement model can be verified, three factors have been evaluated, unidimensional, validity and reliability. After 10 items were dropped out, the data were re-analysed and the findings showed that all 22 items in the measurement model had factor loading meet the required level, all AVE values also meet the required level. While fitness indexes for Absolute Fit, Incremental Fit and Parsimonious Fit all meet the requirements set for all $\mathrm{CR}$ values $\geq 0.6$. Overall, it can be concluded that after the measurement model was modified by dropping 3 items with factor loading $<0.6$ then the model was fit to be used for structural model analysis process.
\end{abstract}

Keywords: Validity, technical teacher, technical vocational college Ministry of Education

\section{Introduction}

Implementation of the Vocational Education Transformation Plan divided into the phase of surge (2011-2013), the phase of improvement (2014-2016) and the phasing phase (2017-2020) has led to a major change to the education system in Vocational Secondary Schools has been transformed into Vocational College (KV) (KPM, 2011). Transformation in $71 \mathrm{KV}$ 's has led to changes in curriculum structure, co-curriculum, working time, assessment system, student recruitment process, infrastructure, level of study, human resources, administrative system, $5 \mathrm{~S}$ system, and more (BPTV, 2012).In implementing a transformation involving all administrators and teachers in the KV, however, the results of the interviews and joint researches with teachers and directors in the ten KV's found many technical teachers involved. This engagement is caused by changes in the curriculum to enable students to be certified with Malaysian Skills Certificate (SKM), which makes teaching and learning skills increase. This view is in line to Stasz et al., (2004) stating that the nature and depth of learning on the technical program is variable according to the desired skill level. In order to achieve a high quality technical education system and effective teaching and learning, the education system should be directed by quality and committed teachers and leaders (Barber \& Mourshed, 2007). 
More specifically, these technical teachers are involved in workshops during teaching and learning sessions, these technical teachers are not provided with laboratory assistants such as teachers teaching science subjects (Sharifah et al., 2013). According to Azarudin (2004), the teachers involved in managing the workshops have other burden of duties such as holding class teacher, subject committee and co-curriculum teacher. Besides having the teaching tasks, the teacher is also assigned to manage workshops and responsible for equipment, inventory, storage of materials, $5 \mathrm{~S}$ and workshop cleanliness, indirectly assigning tasks to their job satisfaction (Azarudin, 2004). This phenomenon is in line with the views stated by Christina Boateng (2012), that the nature and characteristics of technical education presents unique challenges to administrators and organisations, wherein technical institutions require workshops, tools, equipment, and raw materials that will add into teachers daily task at school.

According to Christina Boateng (2012), the technical subjects also require sufficient time for the students to prepare and practice as well as the way students' competence assessment skills are different. All this makes technical education more complicated than the usual education system (Christina Boateng, 2012). According to Sanderson et al., (2000), technical teachers play a role that has a slight difference compared to other academic teachers, as the skills possessed can contribute their opportunities to venture into business with the industry for a salary and welfare is more satisfying than teaching profession. Sanderson et al., (2000) who has been researching in this area in the United States also stated that there are 41.3 percent of technical teachers in the field of intent to leave the teaching profession to venture into another profession.

Ab. Aziz (2007), states that employees are a very important asset to the organisation, without this resource the organisation is unlikely to operate and if these resources are present but vulnerable to various dissatisfaction, conflicts, and disappointments will lead to a shortage of organisational operations. So, Ab. Aziz (2007) also stated that this resource needs to be managed efficiently to achieve optimum productivity levels. Job satisfaction is a key requirement of human being as a worker and must be fulfilled to achieve the level of perfection within the employee. Argyris (1957), Herzberg et al., (1957), McGregor (2005), and Maslow (1954), are early western researchers who emphasise on job satisfaction in an organisation. Shann (1998) has identified the variables that have a direct impact on teacher job satisfaction are important in reducing shifts among teachers.

According to Abdul Rahim (2007), signs of job dissatisfaction among workers in the organisation are workers beginning to show boredom, truancy, low commitment, grievance, protest, resignation, early retirement, loss of trust, stress, performance decline and request for exchanges. In the early stages of Locke's (1976) view of job dissatisfaction could have resulted in absenteeism, quit work, delayed complaints, declining production forces, quickly leaving the office and delayed at rest. Satisfaction level in work affects one to abandon or remain in the profession involved in it (Hagedorn, 1998; Mallam, 1994; \& McBride et al., 1992).

Gruneberg (1979) states that the focus of job satisfaction because of the fact that there is a general perception that job satisfaction can increase productivity and benefit many others to the organisation. Job Satisfaction is a measure of the success of an organisation, if the organisation can provide satisfaction to its employees, not only to enhance the image of an organisation but also to increase the motivation and productivity of all its employees (Sarimah \& Faridatul, 2010). Mohan Raju and Srivastava (1994) emphasise that employees who achieve high levels of satisfaction in work are more committed to the work being undertaken. Shann (1998) also states that job satisfaction is a determinant of commitment to the organisation, while Iskandar et al., (2009) states that elements of emotional intelligence, organisational commitment and job satisfaction are core in building individual and group work performance in an organisation.

The findings of the previous study show that the relationship between emotional intelligence and organisational commitment is influenced by the effects of mediators on job satisfaction (Masoud \& Roya, 2014; Hamed Cherati et al., 2013; Mohamed et al., 2013; Hamid Taboli, 2013; Maryam et al., 2012; Samaneh et al., 2011; Guldal Guleryuz et al., 2008). A study was conducted by Masoud and Roya (2014), a total of 250 workers in banks organisation in Kerman, Iran were involved and analyses were conducted to see if there were intermediary effects or organisational commitment mediators in job satisfaction relationships with work performance. The results showed that there was a positive correlation between job satisfaction and work performance. The results showed that there was a positive correlation between job satisfaction and work performance. The findings also show that respondents with high levels of commitment in their work show better performance (Masoud \& Roya, 2014).

While the study conducted by Guldal Guleryuz et al., (2008) involving 267 nurses in the Hospital in Ankara, Turkey relates to job satisfaction as a mediating effect between emotional intelligence and organisational commitment, found that job satisfaction affects the mediator between emotional intelligence and commitment organisation. In addition, studies conducted by Kelly and Caplan (1993), Cooper and Sawaf (1997) and Abraham (2000) have stated that emotional intelligence is able to influence employee satisfaction and commitment to the organisation. Relationships of emotional intelligence, job satisfaction and limited organisational commitment are studied in the field of social science (Gardner \& Stough, 2003).

Sy et al., (2006) found that employees with high levels of emotional intelligence are more likely to have higher levels of job satisfaction as they are more skilled in evaluating and controlling their own emotions than those with low levels of emotional intelligence. However, Abraham (2000) found that the relationship between emotional intelligence was stronger with organisational commitment than job satisfaction. Yang and Chang (2007) also found that job 
satisfaction had the impression of mediators in the relationship of emotional intelligence and organisational commitment. If the problem of teacher dissatisfaction is not thoroughly examined, the field of education will not only have the problem of non-committed, non-dedicated, non-professional teachers, but will also lose quality teachers and consequently affect productivity and quality in education systems (Ruhland, 2001).

\section{The Framework of Job Satisfaction Theory}

Rosli (1998), states that today's world of job satisfaction is very important in an organisation, especially when it comes to the management of human capital psychology. The importance of job satisfaction in an organisation is important as it relates to physical and emotional health of employees (Oshagbemi, 2000). Job satisfaction is associated with both psychological and physical perspectives, hence it is recognised as a complex construct that includes internal factors and external factors (Herzberg, Mausner, \& Snyderman, 1959). Herzberg et al., (1959) identifies intrinsic factors pertaining to inpatient rewards while extrinsic factors are due to external rewards such as wages, organisational practices and policies, oversight, interpersonal relationships with organisational supervision and organisational culture.

McKinnon et al., (2003), confirms that organisational culture that values its employees, organisational stability, and aggressive organisations can cause high levels of job satisfaction among its employees. Job satisfaction is an important predictor of organisational commitment and absenteeism (Baroudi, 1985; Igbaria \& Greenhaus, 1992; Moynihan \& Pandey, 2007; Spector, 1997) and relate to work performance (Osterman, 1995). Empirical evidence suggests a positive relationship between organisational commitment and job satisfaction (Falkenburg \& Schyns, 2007; Williams \& Hazer, 1986) and the relationship between job satisfaction with job absence is also positive (Falkenburg \& Schyns 2007; Sagie, 1998). In the same vein, Keller et al., (1996) examines the relationship between job satisfaction and productivity and the results are very positive, this finding is supported by the study of Chen et al., (2004). In this study, the framework of job satisfaction theory is based on two models namely 1) Model Abraham Maslow (1954), and 2) Model Herzberg (1968).

\subsection{Model Abraham Maslow}

Maslow (1954), writes in his book titled Motivation and Personality, there are five levels of human needs namely physiology, safety, love, self-respect, and self-perfection (Sidek \& Mardiana, 1999). According to Maslow (1954), the need for self-development can provide lasting motivation, as it is important to know the primary and secondary needs of a person. According to experts in psychology, when the basic needs reach the level of satisfaction, the individual will work to meet the needs to the next level, otherwise if the individual does not achieve the level of satisfaction at the basic needs level then the desire for higher level will not be continued (Sidek \& Mardiana, 1999).

The Maslow's Hierarchy of Needs Model (1954) is the earliest model of motivation, which is the first level in this model is physiological needs and increases to the level of self-actualisation. In this model, it is clear that human beings need to work to fulfill their needs in their lives. Maslow (1954) stated that basic needs are food, clothing and shelter. After this requirement is fulfilled, an individual will try to get the higher requirements of safety, social, achievement and recognition. The theory pointed out by Maslow (1954) is a humanistic approach that places humanity is rational and is always in contact with oneself or with others. Implications of this nature will be the behaviour of a person that causes various methods of birth to fulfill self-indulgence (Sidek \& Mardiana, 1999).

According to the theory presented by Maslow (1954), human beings have the need for something, to meet human needs ranging from the lowest levels and must be fulfilled with physiological needs such as eating, drinking, air for breathing, work time, rest time, sex and etc., while the second level is the security requirement that guarantees protection and wellbeing for survival. The third level requirement is socialising, meaning that the human will be silent if they cannot interact and communicate and play a certain role in the social institutions it represents. The fourth rating is self-esteem, here they are hoping to be honoured, respected and praised that needs more comfort to meet individual tastes. Finally, the highest requirement is to get a place of self-perfection.

Maslow (1954) emphasises that each individual must move in full and cannot move only part of the achievement of a goal. He said that someone would be motivated to achieve that goal. It clearly shows that one goal is to be met by all people regardless of generation, environment and culture. Self-satisfaction is the highest level of hierarchical theory proposed by Maslow (1954). In that context, in the case of an individual's job is satisfied with doing work when the individual is valued while in the organisation. The rewards given by the organisation will make one feel pride, ability, usefulness and merit to the organisation. Maslow (1954) states that individuals are satisfied when they have achieved the level of self-perfection and otherwise they have restlessness and anxiety in daily life.

From Maslow's theory (1954) this clearly demonstrates a strong link between work, commitment and motivation. This theory is very suitable to be used as a basis for studying the commitment of technical teachers in vocational colleges in their involvement in the teaching profession. The theory presented by Maslow (1954) clearly indicates that one must actively engage in achieving self-perfection. According to Covey (1989), to meet the demands of person's needs, it is necessary to be committed in his work because if there is no commitment to his work where possible personal perfection can be achieved. From Maslow's theory (1954) this clearly demonstrates a strong link between work, commitment and motivation. This theory is very suitable to be used as a basis for studying the commitment of technical teachers in vocational colleges in their involvement in the teaching profession. 


\subsection{Model Herzberg}

Herzberg's Motivators and Hygiene Factors or Two Factors Theory relates factors that can provide job satisfaction or otherwise. This theory is related to Maslow's Motivation Theory (Maslow, 1954). Herzberg emphasizes on the steps that meet the needs of the higher level according to Maslow's Theory (Maslow, 1954). These requirements include achievement, recognition, responsibility, progress and the type of work being undertaken. However, Herzberg (1968) adds a two-factor model of motivation, which has two types of work that will result in job satisfaction. According to him, hygiene factors such as position, permanent work, salary and convenience cannot motivate. But the inability will result in employee dissatisfaction.

But Herzberg (1968) adds a two-factor model of motivation, with two types of work that each work will result in job satisfaction. According to him, hygiene factors such as position, permanent work, salary and convenience cannot motivate. But the inability will result in employee dissatisfaction. According to this theory, if an employee believes that doing an activity will bring about a certain consequence, it will influence the choice, the way and the level of effort. Herzberg's Theory (1968), has been criticized based on the way it is used. It also does not take into account the personality traits of the employees. However, employees who get satisfaction in their work do not necessarily work better. But this way can help management to use scientific ways to understand the motivational problems at work. In Herzberg's Theory (1968), he took into account two key aspects of motivation and job satisfaction. Herzberg (1968) has categorized one's desire into two, namely the desire of hygiene and motivator's desire.

(a) Motivator's desire is a stage of desire at a high level, this ranking by itself motivates a person to achieve high achievement. It is linked to the internal factors of work such as achievement success, work situation itself, responsibility and recognition.

(b) Hygiene desires are linked to a person's well-being, linked to an out of the job desire but involves working environments including wages, employment status, organisational administration policies, supervision, employer relationships with employers, relationships with supervisors, workplace and job security.

This motivator factors will make the employees satisfied with their jobs if it is filled. Otherwise, it does not cause an employee to experience dissatisfaction with his work, he only ranked neutral only. Unlike hygiene factors if not fulfilled can cause an employee to be dissatisfied with his job, if satisfied make the employee feel satisfied but only at a neutral level. This suggests that hygiene factors only have a slight influence to produce workers feeling satisfied with their work. Herzberg (1968), states that organisations should not have inadequate administrative systems, restrictions on rewards and the factors that impede the implementation of the work better. Mahmood Nazar (2001) states that a good working environment will accelerate the worker's self-development to a better level.

\subsection{Job Satisfaction Questionnaire}

There are various questionnaires that are used to measure job satisfaction in the organisation. There are various questionnaires that are used to measure job satisfaction in the organisation. In this study only three popular questionnaires were used in local studies and overseas studies were presented. The questionnaire was Job Satisfaction Survey (JSS), Job Descriptive Index (JDI) and Minnesota Satisfaction Questionnaire (MSQ).

Job Satisfaction Survey (JSS) was developed by Spector (1985) to assess employee attitudes about work and work aspects. JSS is a 32-item questionnaire that delivers eight separate aspects related to job satisfaction. The eight aspects mentioned are salary, promotion, benefits, supervision, operational procedures, colleagues, working methods, and communication. The answer to each item is based on likert scale 7 points rather than very disagree to very agree.

Minnesota Satisfaction Questionnaire (MSQ) was developed in 1967 by Weiss, Dawis, England, and Lofquist (Tara Yost Bane, 2006), MSQ has become a widely used tool for assessing job satisfaction. Three versions of MSQ have been developed, two versions have 100 items namely 1977 and 1967 versions. Have been reduced to 20 items in the 3rd version. MSQ is intended to measure the aspects of employee satisfaction with their respective work, and it provides more information to aspects of job rewards rather than doing more general steps of job satisfaction. MSQ has been widely used in studies exploring customer needs, counselling, and for information on job-strengthening (Vocational Psychology Research, 2002). In this study, researchers using the Job Satisfaction Survey (JSS) questionnaire were developed by Spector (1985) to evaluate the attitude of technical teachers on work and work aspects. Among the researchers using JSS are Iskandar Padzil et al., (2013), Noorhafeza and Ferlis (2010), Nor Liyana and Mansor Abu Talib (2010) and Mohd Shaladdin Muda and Nik Wan Omar (2006).

\section{Methodology}

The design of this study is based on a descriptive survey study, inferences and hypothesis testing to find answers to research issues that have been raised. In general, research can be conducted by exploratory, descriptive and inference by Creswell's (2012). According to Chua (2011) one study was conducted to find the answer to the uncertainty of an issue, the uncertainty cannot be solved only with the viewpoint of the researcher as the researcher's views and 
knowledge may arise from beliefs, cultures, traditions, stereotypes, wrong responses and influences the authorities. In this study, the Structural Equation Modelling (SEM) approach and the Analysis of Moment Structures (AMOS) software in analysing and verifying the proposed model at the pre-stage of the study were used. This approach has been widely used in several disciplines, including banking, healthcare, information management, logistics, marketing, psychology, and tourism management ( $\mathrm{Lu}$ et al., 2007). A total of 865 questionnaires were distributed and 609 were returned to researchers. The one-to-one review process on the questionnaires was carried out, only completed questionnaires were answered for analysis. The total population is 1320 consists of involved technical teachers in electrical and electronics engineering, civil engineering and mechanical engineering from 25 Vocational Colleges throughout Malaysia, broken down into five zones: North Zone, South Zone, East Coast Zone, Central Zone and East Malaysia Zone (Sabah, Sarawak and the Federal Territory of Labuan). Hence the generalization made is only for the context of this study and a more comprehensive follow-up study should be used to overcome this limitation.

\subsection{Outlier Data}

The researcher distributed 865 questionnaires and 609 of them were returned, the percentage of return of the questionnaire was $70.40 \%$. The rate of return of the questionnaire has exceeded $50 \%$ proposed by Creswell (2015). Incomplete questionnaires were removed from data processing, out of 609 questionnaires received 23 of them were incomplete, a total of 586 questionnaires could be analysed. A total of 586 completed questionnaires were key in on SPSS software version 20 and subsequently using AMOS version 21 software. The data outlier detection was performed with the most distant observation of the centre, Mahalanobis Distance (Iman Ghozali, 2008; Tabachnick and Fidell, 2007). The criterion used is based on the value of Chi-squares Distribution Table on the degree of fredom, the number of construct items at the significant level of $p<0.001$ as suggested by Tabachnick and Fidell, (2001). The value of Mahalanobis Distance in this study is $\mathrm{x} 2=143.344$, $\mathrm{df}=95, \mathrm{p}<0.001$ ) where the value greater than 143.3 .44 is the data that is out lies and discarded from the data for analysis. Finally, as many as 493 sets of data are desirable to be analysed, the remaining sample sizes still meet the criteria of the minimum sample size survey proposed by Hair et al., (2006)

\subsection{Normality Test}

Normality tests were carried out on data after the isolation process, the researchers used the skewness and kurtosis method (Hishamuddin, 2005 \& Zainudin, 2012). The data are normally distributed if the skewness and kurtosis values are within the range of \pm 1 (Zainudin, 2012 \& Hisyamuddin, 2005). According to Zainudin (2015) also if samples over 200 skewness and kurtosis values can be up to \pm 1.5 . While Tabachnick and Fidell (2007) suggest data normality based on skewness and kurtosis values at \pm 2 range for large samples. In this study, researchers use what Tabachnick and Fidell (2007) suggest, as a result of the normality of the study data show all values are within the permissible range.

\section{Findings and Discussion}

Confirmatory factorial analysis (CFA), this CFA analysis is conducted to answer the question of the study. It is to verify the measurement model of job satisfaction constructs among technical teachers in electrical and electronics engineering, civil engineering and mechanical engineering at Vocational College, KPM. To ensure this measurement model can be used there are three things in the value, 1) Unidimensional (see loading factor value $\geq 0.6$ ), 2) Validity (convergent validity $\mathrm{AVE} \geq 0.5$, construct validity refers to fitness indexes and discriminant validity) and 3) Reliability (composite reliability, $\mathrm{CR} \geq 0.6$ and Average Variance Extracted $\geq 0.5$ ) (Zainudin, 2015). According to Zainudin (2015) discriminant validity is only calculated for the combined model and only the main constructs. Composite Reliability (CR) and Average Variance Extracted (AVE) are calculated using the formula, $\mathrm{CR}=(\Sigma \mathrm{K}) 2 /[(\Sigma \mathrm{K}) 2+(\Sigma 1$ $-\mathrm{K} 2)$ ] and AVE $=\Sigma \mathrm{K} 2$ / loading of each item and $\mathrm{n}$ is the number of items in the measurement model.

Fitness Index measurement model is based on (i) RMSE $\leq 0.008$ (The Root Mean Square of Error Approximation) (ii) IFI $\geq 0.9$ (Incremental Fit Index) (iii) CFI $\geq 0.9$ (Comparative of Fit Index) 0.9 (Tucker Lewis Index) and (v) Chisq / df $\leq 3.0$ (Chi Square / Degree of Freedom). If the analysed model is less matched by Zainudin (2015) and Hair et al., (2006) recommends that modifications to the model be performed by checking the factor loading factor for each item to exceed 0.6 , items less 0.6 should be dropped and if the match index has not been reached revision to the modification index (MI) based on $\mathrm{MI} \geq 15$, the item needs to be boiled.

CFA analysis is performed to confirm the relationships of the job satisfaction constructs. The results of the EFA analysis suggested four sub-constructs of the job satisfaction namely salaries, supervisors, side benefits and climate in the organisation. The purpose of conducting this CFA analysis is to examine the compatibility model of job satisfaction measurement with 22 items. After data is analysed, the model of job satisfaction in Figure 1. 


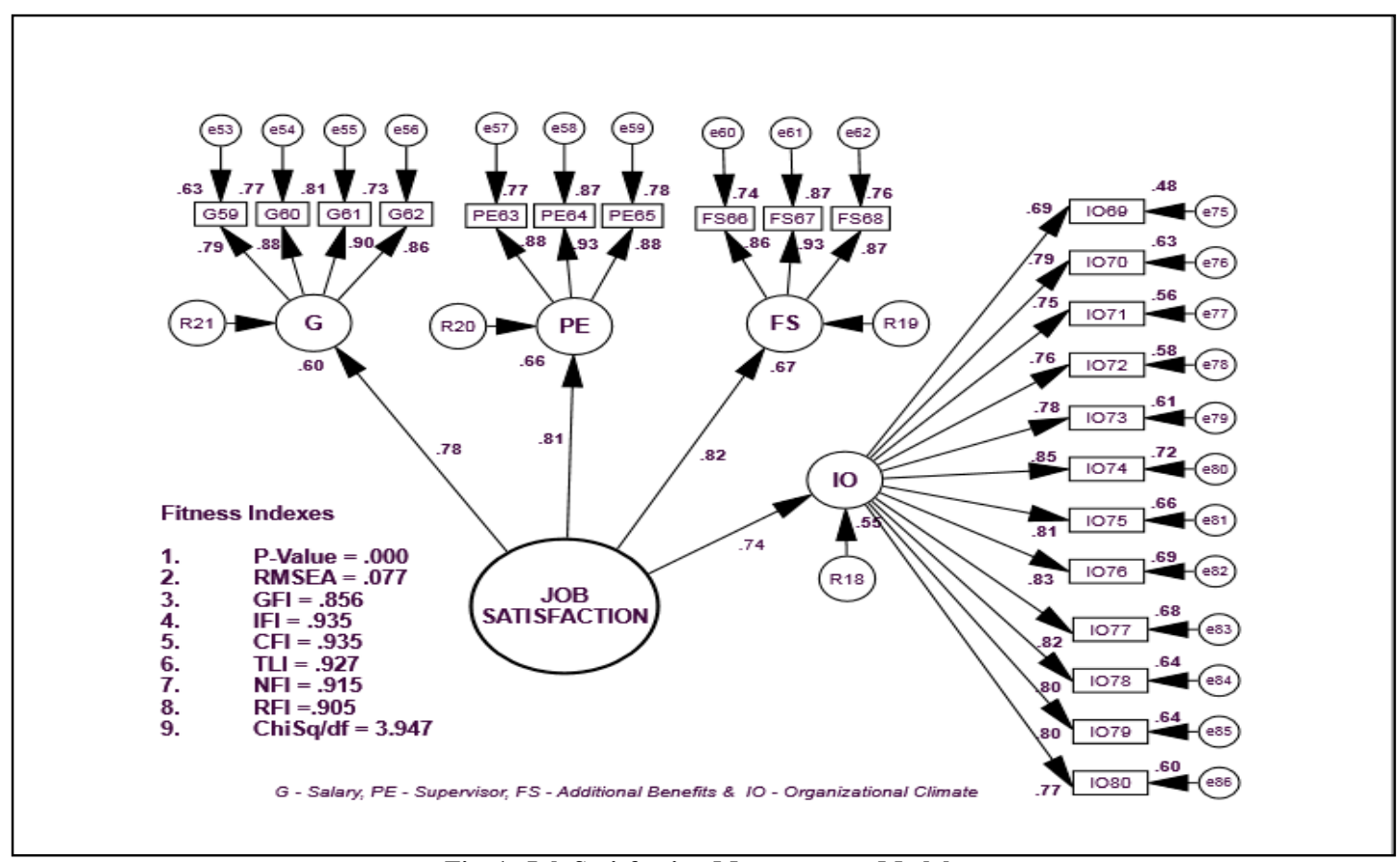

Fig. 1- Job Satisfaction Measurement Model

\subsection{Unidimensional}

To ensure the measurement model developed is unidimensional then all items that measure construct or substructure should have loading factor $\geq 0.6$. Ay item lower than 0.6 should be dropped from the model. Unidimensional is achieved when all measuring items have acceptable factor loading for the respective latent construct (Zainuddin 2015). According to Zainuddin (2015), in order to ensure unidimensional of a measurement model, any item with a low factor loading should be deleted. For a newly developed item, the factor loading for every item should exceed 0.5 and for established items, the factor loading for every item should be 0.6 or higher. In this study, the researcher uses the Job Satisfaction Survey (JSS) item, developed by Spector (1985), so the minimum value of loading factor applied is 0.6 and above. Figure 1 shows that the factor loading for the entire items for the job satisfaction construct.

\subsection{Validity}

Validity is the ability of instrument to measure for a latent construct, three types of validity are required for each measurement model is construct validity, convergent validity and discriminate validity (Zaidnuddin, 2015). The validity constraints will be fulfilled when the fitness index meet the minimum requirements specified, referring to Figure 4.4 the compatibility index for this model has not reached the prescribed level of RMSEA $=0.077, \mathrm{CFI}=0.935$ and Chisq/df $=3.947$. Hence, to ensure that the compatibility index is fulfilled, this modelling model needs to be modified by looking at the Modification Index (MI), as proposed by Zainudin (2015). There are two methods to do, 1) remove one of these items (remove the item that has a lower loading factor) or looping the item specified from the MI. In this study, the researcher chooses to make looping items based on MI's highest so that the model fulfils the set of compatibility index. Items that need to be looped are as shown in Table 1. This process is done one by one and the model's re-analysis is carried out until its matching index meets the minimum level, the items involved are items IO79 with IO80, IO78 items with IO79, Item IO75 with IO76 and Item IO69 with IO70. After the measurement model is reanalysed, the modified model is shown in Figure 2, the value of the corresponding index readings is RMSEA $=0.063$, $\mathrm{CFI}=0.958$ and $\mathrm{Chi}$ sq $/ \mathrm{df}=2.943$ these values meet the minimum requirements set, the summary is in Table 2 .

To meet the second validity requirement, convergent validity is satisfied, the value of Average Variance Extracted (AVE) for all constructs and sub-constructs of job satisfaction should be calculated, the AVE value should be $\geq 0.5$. Having made the AVE calculation for the job satisfaction construct is 0.626 as summarised in Table 3 , for the substructures payroll is 0.737 , the supervisor is 0.805 , the side benefit is 0.787 and the climate in the organisation is 0.610 , summarised in Table 4 . 
Table 1 - Modification Indices of Job Satisfaction Item

\begin{tabular}{cccccc}
\hline & & & M.I. & Par Change & Comment \\
\hline e85 & $<-->$ & $\mathrm{e} 86$ & 63.028 & .056 & Item IO79 \& IO80 \\
e84 & $<-->$ & $\mathrm{e} 86$ & 47.474 & .052 & \\
$\mathrm{e} 84$ & $<-->$ & $\mathrm{e} 85$ & 82.310 & .063 & Item IO78 \& IO79 \\
$\mathrm{e} 82$ & $<-->$ & $\mathrm{e} 83$ & 16.053 & .025 & \\
$\mathrm{e} 81$ & $<-->$ & $\mathrm{e} 82$ & 65.422 & .051 & Item IO75 \& IO76 \\
$\mathrm{e} 80$ & $<-->$ & $\mathrm{e} 84$ & 17.034 & -.026 & \\
$\mathrm{e} 77$ & $<-->$ & $\mathrm{e} 78$ & 25.764 & .040 & \\
$\mathrm{e} 76$ & $<-->$ & $\mathrm{e} 77$ & 23.549 & .035 & \\
$\mathrm{e} 75$ & $<-->$ & $\mathrm{e} 76$ & 32.347 & .046 & \\
$\mathrm{e} 53$ & $<-->$ & $\mathrm{e} 56$ & 18.722 & -.048 & \\
\hline
\end{tabular}

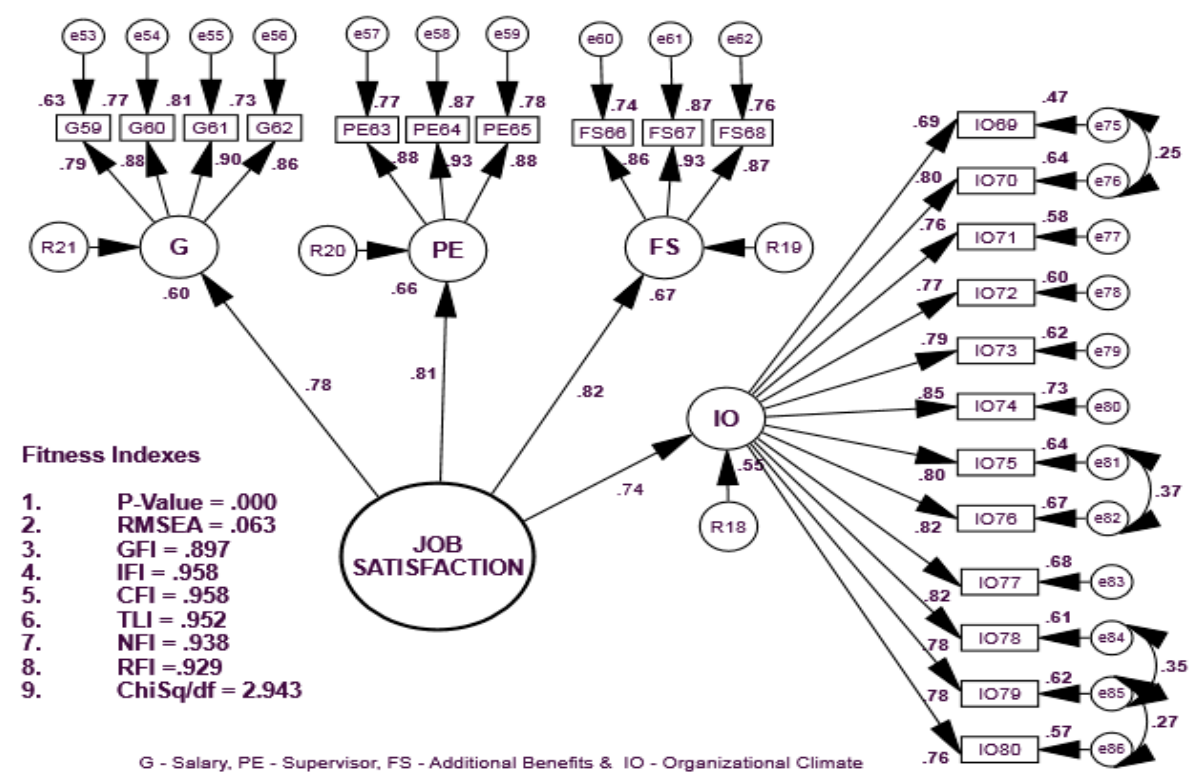

Fig. 2 - Modify Job Satisfaction Measurement Model

Table 2 - Summary of Indexes Fitness Job Satisfaction Measurement Model

\begin{tabular}{|c|c|c|c|c|c|}
\hline & Category & Index & $\begin{array}{c}\text { Index Value Model } \\
\text { Hypothesis } \\
\end{array}$ & $\begin{array}{l}\text { Modified Model } \\
\text { Value Index } \\
\end{array}$ & Comment \\
\hline \multirow[b]{2}{*}{1.} & \multirow[b]{2}{*}{ Absolute Fit } & RMSEA & 0.077 & 0.063 & Meet the required level $(\leq 0.08)$ \\
\hline & & GFI & 0.856 & 0.958 & $\begin{array}{l}\text { Does not meet the required } \\
\text { level }(\geq 0.90)\end{array}$ \\
\hline \multirow{2}{*}{2.} & \multirow{2}{*}{ Incremental Fit } & CFI & 0.935 & 0.952 & Meet the required level $(\geq 0.90)$ \\
\hline & & TLI & 0.927 & 0.938 & Meet the required level $(\geq 0.90)$ \\
\hline 3. & Parsimonious & Chi sq/df & 3.947 & 2.943 & Meet the required level $(\leq 3.00)$ \\
\hline
\end{tabular}

\subsection{Reliability}

Reliability is the extent of how reliable is the said measurement model in measuring the intended latent construct, the assessment for reliability indicates for a measuring the intended latent (Zainuddin, 2015). The reliability of this model is identified by computing the value of Composite Reliability $(C R \geq 0.6)$ which is the $C R$ which demonstrates the 
reliability of the item and internal consistency. The findings from the calculation show that composite reliability for substructures payroll is 0.918 , supervisor is 0.925 , side benefit is 0.917 and organisational climate is 0.935 , as summarised in Table 3. CR for job satisfaction constructs is 0.870 , as summarised in Table 4

Table 3 - Composite Reliability (CR) and Average Variance Extracted (AVE) for First Order Constructs

\begin{tabular}{|c|c|c|c|c|}
\hline Sub-Construct & Item & Loading Factor & $\mathrm{CR}(\geq 0.6)$ & AVE $(\geq 0.5)$ \\
\hline \multirow{4}{*}{$\begin{array}{c}\mathrm{G} \\
\text { (Salary) }\end{array}$} & G59 & 0.79 & \multirow{4}{*}{0.918} & \multirow{4}{*}{0.737} \\
\hline & G60 & 0.88 & & \\
\hline & G61 & 0.90 & & \\
\hline & G62 & 0.86 & & \\
\hline \multirow{3}{*}{$\begin{array}{c}\mathrm{PE} \\
\text { (Supervisor) }\end{array}$} & PE63 & 0.88 & \multirow{3}{*}{0.925} & \multirow{3}{*}{0.805} \\
\hline & PE64 & 0.93 & & \\
\hline & PE65 & 0.88 & & \\
\hline \multirow{8}{*}{$\begin{array}{c}\text { FS } \\
\text { (Additional Benefits) }\end{array}$} & FS66 & 0.86 & \multirow{3}{*}{0.917} & \multirow{3}{*}{0.787} \\
\hline & FS67 & 0.93 & & \\
\hline & FS68 & 0.87 & & \\
\hline & IO69 & 0.69 & \multirow{12}{*}{0.935} & \multirow{12}{*}{0.610} \\
\hline & IO70 & 0.80 & & \\
\hline & IO71 & 0.76 & & \\
\hline & IO72 & 0.77 & & \\
\hline & IO73 & 0.79 & & \\
\hline \multirow{7}{*}{$\begin{array}{c}\text { IO } \\
\text { (Organisational Climate) }\end{array}$} & IO74 & 0.85 & & \\
\hline & IO75 & 0.80 & & \\
\hline & IO76 & 0.82 & & \\
\hline & IO77 & 0.82 & & \\
\hline & $\mathrm{IO} 78$ & 0.78 & & \\
\hline & IO79 & 0.78 & & \\
\hline & IO80 & 0.74 & & \\
\hline
\end{tabular}

Table 4 - Composite Reliability (CR) and Average Variance Extracted (AVE) for Second Order Constructs

\begin{tabular}{ccccc}
\hline Construct & Sub Construct & Loading Factor & CR ( $\geq$ 0.6) & AVE ( $\geq$ 0.5) \\
\hline \multirow{3}{*}{ Job Satisfaction } & G & 0.78 & & 0.626 \\
& PE & 0.82 & 0.870 & \\
\hline
\end{tabular}

\section{Conclusion}

After the analysis was conducted on 586 questionnaires with the original items of 32 items and dropped 10 items, the total number of final items for this measurement model is 22 items. This measurement model can be verified by taking into account the value of 1) Unidimensional (see loading factor value $\geq 0.6$ ), 2) Validity (convergent validity AVE $\geq$ 0.5 , construct validity refers to fitness indexes and discriminant validity) and 3) Reliability (composite reliability, CR $\geq$ 0.6 and Average Variance Extracted $\geq 0.5$ ). The findings of the analysis show that all the conditions have been fulfilled. The structural equation modelling analysis is divided into two, namely the measurement model analysis and the structure model analysis. Measurement model is used to measure latent variables through the variables indicator. This measurement model was analysed covering the relationship between items with constructs, correlations between constructs and measurement errors for each item. Unidimensional, validity and reliability are important in developing the instrument model, to ensure that these items can be used in developing the structure model for this study. Finally, the measurement model that has undergone this CFA analysis has been verified. The total number of items left after the CFA process has resulted in the items being dropped due to the low loading factor of 0.6. After the process of unidimensional, validity, reliability and discriminant validity, analysis of this measurement model has verified its usability for structural model analysis purposes.

\section{References}

Abraham, R. (2000). The Role of Job Control in Emotional Dissonance and Emotional Intelligence Outcome Relationships. The Journal of Psychology, 134, 169-184. 
Ab. Aziz, Y. (2007). Keinsanan Dalam Pengurusan. Utusan Publications \& Distributors Sdn. Bhd., Kuala Lumpur, Malaysia.

Abdul Rahim Abd. Rashid. (2007). Profesionalisme Keguruan Prospek dan Cabaran. Kuala Lumpur: Dewan Bahasa dan Pustaka.

Argyris, C. (1957). Personality and Organisation. New York: Harper and Row Publishers.

Azarudin (2004). Beban Tugas Guru Bengkel Dalam Pengurusan Bengkel di Lima Buah Sekolah Menengah Teknik di Negeri Sembilan. Universiti Teknologi Malaysia.

Barber, M., dan M. Mourshed (2007). "How the World's Best Performing Schools Come out on Top." McKinsey \& Company, New York, USA. http://mckinseyonsociety.com/how-the-worlds-best-performing-schools-come-out-ontop/.

Bahagian Pendidikan Teknik dan Vokasional (BPTV) (2012). Laporan Tahunan 2012. Diterbitkan oleh BPTV, KPM.

Baroudi, J.J. (1985). The Impact of Role Variables on IS Personnel Work Attitudes and Intentions. MIS Quarterly, 9(4), 341-356.

Chen, R., K. Ersi, J. Yang, S. Lu and W. Zhao (2004). Validation of Five Global Radiation Models with Measured Daily data in China. Energy Conversion and Management 45(11-12): 1759-1769.

Christina Boateng (2012). Restructuring Vocational and Technical Education in Ghana: The Role of Leadership Development.International Journal of Humanities and Social Science Vol.2 No.4. di http://ijhssnet.com/journals/Vol2_No4_Special_Issue_February_2012/15.pdf

Cooper, R.K. and Sawaf, A. (1997). Executive EQ: Emotional Intelligence in Leadership and Organisations, New York: Grosseflutnam.

Covey S. R. (1989). The Seven Habits of Highly Effective People. New York: Simon and Schuster.

Falkenburg, K., and Schyns, B. (2007). Work Satisfaction, Organisational Commitment and Withdrawal Behaviours. Management Research News, 30 (10), 708-723.

Gardner, L. and Stough, C. (2003). Assesing the Relationship Between Workplace Emotional Intelligence, Job Satisfaction and Organisational Commitment. Australian Journal of Psychology, 2003, 55, 124-155.

Gruneberg, M. M. (1979). Understanding job satisfaction. New York: Macmillan.

Guldal Guleryuz, Semra Guney, Eren Miski Aydın and Oznur Asan (2008). The Mediating Effect of Job Satisfaction between Emotional Intelligence and Organisational Commitment of Nurses: A Questionnaire Survey. International Journal of Nursing Studies 45 (2008) 1625-1635.

Hair, Jr., J. F., Black, W. C., Babin, B. J., Anderson, R. E., \& Tatham, R. L. (2006). Multivariate Data Analysis (6th ed.). Uppersaddle River, New Jersey: Pearson Education International, Inc.

Hamed Cherati, Iraj Mahdavi and Javad Rezaeian (2013).The Mediating Role of Job Satisfaction between Spiritual Intelligence and Organisational Commitment. International Journal of Research in Organisational Behavior and Human Resource Management.

Hamid Taboli (2013). Job Satisfaction as a Mediator in Relationship between Emotional Intelligence, Organisational Commitment in Employees' Kerman Universities. Life Science Journal 2013;10(1).

Herzberg, F., Mausner, B., Peterson, R., and Capwell, D. (1957). Job Attitudes: Review of Research and Opinion. Pittsburg: Psychological Service of Pittsburg.

Hebzberg, F., Mausnek, B., and Snydebman, B (1959). The Motivation to Work (Second Edition). New York: John Wiley and Sons.

Herzberg, F.B (1968). Motivation to Work. New York: John Wiley and Son Inc.

Hagedorn, L. S. (1998). Implications to postsecondary faculty of alternative calculation methods of gender-based wage differentials. Research in Higher Education, 39, 143.

Hishamuddin Md. Som (2005). Panduan Mudah Analisis Data Menggunakan SPSS Windows. Skudai, Johor : Universiti Teknologi Malaysia.

Iman Ghozali (2008). Model Persamaan Struktural Konsep dan Aplikasi Dengan Program Amos 16.0. Penerbit Universitas Diponegoro Semarang, Indonnesia. 
Iskandar, Rohaty Mohd. Majzub dan Zuria Mahmud (2009). Kecerdasan Emosi dan Komitmen Pekerjaan dalam Kalangan Pensyarah Universiti di Indonesia. Jurnal Pendidikan Malaysia 34(1)(2009).

Iskandar Padzil, Foo Say Fooi dan Ramli Basri (2013). Kepuasan Kerja Dalam Kalangan Guru Sekolah Menengah Kebangsaan Agama. Seminar Pasca Siswazah Dalam Pendidikan (GREDUC 2013).

Igbaria, M., and Greenhaus, J. H. (1992). Determinants of MIS Employees' Turnover Intentions: A Structural Equation Model. Communications of the ACM, 35(2), 34-51.

Kementerian Pendidikan Malaysia (2011). Pelan Strategik Transformasi Pendidikan Vokasional: Bahagian Pendidikan Teknik dan Vokasional. 2014.http://www.bptv.edu.my/v4/images/bahanpdf/pelanstrategiktpv/ PelanStrategikTranformasiPendidikanVokasional_1.pdf

Kelley, R., and Chaplan, J. (1993). How Bell Labs Creates Star Performers. Harvard Business Review, 71, $128-139$.

Keller, R., Julian, S. D., and Kedia. B. L. (1996). A Multinational Study of Work Climate, Job Satisfaction, and the Productivity of RandD Teams. IEEE Transactions on Engineering Management, 43(1), 48-55.

Lu, C.S., Lai, K., Cheng, T., (2007). Application of Structural Equation Modelling to Evaluate the Intention of Shippers to Use Internet Services in Liner Shipping. Eur. J. Oper. Res. 180, 845-867.

Locke, E.A. (1976). Organisational Commitment, Job Satisfaction and Turnover Among Psychiatric Technicians. Journal of Applied Psychology (pp.1297-1349). Chicago: Rand McNally.

Mahmood Nazar Mohamed (2001). Penghantar Psikologi Satu Pengenalan Asas Kepada Jiwa dan Tingkahlaku Manusia. Kuala Lumpur : DBP.

Maslow A (1987). Motivation and Personality (3rd edition) New York: Harper and Row.

Mallam, U. (1994). A National Research Study on Factors Influencing Faculty Turnover at Selected Nigerian Colleges of Technology/polytechnics. Higher Education, 27, 229.

Maslow, Abraham Harold (1954). Motivation and Personality. New York: Harper.

Maryam Nikkheslat, Zeinab Seyed Saleki, Reza Asgharian and Roozbeh Hojabri (2012). The Relationship between Emotional Intelligence and Organisational Commitment: The Mediating Role of Job Satisfaction. International Journal of Research in Management and Technology.

Masoud Hasanzadeh and Roya Davari (2014). Organisational Commitment as a Mediator in Relationship between Job Satisfaction and Work Performance among Bank Employees in Kerman. Reef Resources Assessment and Management Technical Paper, Vol. 40 (4), 2014, 1, pp 573-57. www.behaviorsciences.com

McKinnon, L. J., Harrison, L. G., Chow, W. C., and Wu, A. (2003). Organisational Culture: Association with Commitment, Job Satisfaction, Propensity to Remain, and Information Sharing in Taiwan. International Journal of Business Studies, 11(1), 25- 44.

McBride, S. A., Munday, R. G., and Tunnell, J. (1992). Community College Faculty Job Satisfaction and Propensity to Leave. Community / Junior College Quarterly, 16, 157.

Mohan Raju and Srivastava (1994). Factors Contributing to Commitment to the Teaching Profession. International Journal of Educational Management, 8 (5) (1994), pp. 7-13.

Mohd Shaladdin Muda dan Nik Wan Omar (2006). Model Peramal Kepuasan Kerja Pegawai Perkhidmatan Pendidikan di Kumuniti Pesisir Terengganu. IJMS $13 \quad$ (Special $\quad$ Issue), $123-142$. http://ijms.uum.edu.my/images/pdf1/13SPijms/ijms.

Mohamed A. Rageb, Eman Mohamed Abd-El-Salam, Ahmed El-Samadicy and Shaimaa Farid (2013). Organisational Commitment, Job Satisfaction and Job Performance as a Mediator between Role Stressors and Turnover Intentions A Study from an Egyptian Cultural Perspective. International Academic Conference (IACD) Dubai.

Moynihan, D. P. and Pandey, S. K. (2007). The Role of Organisations in Fostering Public Service Motivation. Public Administration Review, 67: 40-53.

McGregor, D. (2005). The Human Side of Enterprise, Annotated Edition. McGraw Hill; 1 Edition.

Noorhafeza Herliani Adey dan Ferlis Hj. Bahari (2010). Hubungan antara Kecerdasan Emosi, Kepuasan Kerja dan Komitmen Terhadap Organisasi. Kemanusiaan bil.16, http://www.management.utm.my/download/doc_download/421-hubunganantara-kecerdasan-emosi-kepuasan-kerjadan-komitmen-terhadaporganisasi.html. 
Nor Liyana Mohd Bokti dan Mansor Abu Talib (2010). Tekanan Kerja, Motivasi dan Kepuasan Kerja Tentera Laut Armada Tentera Laut Diraja Malaysia. Jurnal Kemanusiaan bil.15.

Oshagbemi, T. (2000). Gender Differences in the Job Satisfaction of University Teachers. Women in Management Review, 15(7), 331-343.

Osterman, Paul, (1995). Skill, Training, and Work Organisation in American Establishments,Industrial Relations, vol. 34, no. 2 pp. $125-146$.

Ruhland S.K. (2001). Factors that Influence the Turnover and Retention of Minnesota's Technical College teachers. Journal of Vocational Education Research.

Rosli Arup (1998). Hubungan Persepsi Faktor Organisasi Dengan Kepuasan Kerja Kakitangan Jabatan Agama Islam Sarawak. Kertas Projek: Universiti Pertanian Malaysia, Serdang, Selangor.

Sagie, A. (1998). Employee Absenteeism, Organisational Commitment, and Job Satisfaction: Another Look. Journal of Vocational Behavior, 52, 156-171.

Sanderson, A., Phua, V. C., \& Herda, D. (2000). The American Faculty Poll. Chicago: National Opinion Research Center. dihttp://www. norc.org/PDFs/publications/SandersonA_Amer_Faculty_Poll_2000.pdf

Sarimah Ismail dan Faridatul Akmar Talip (2010). Kepuasan Bekerja Staf Akademik Jabatan Pendidikan Teknikal dan Kejuruteraan, Fakulti Pendidikan, Universiti Teknologi Malaysia, Skudai. pp. 1-7

Samaneh Aghdasi, Ali Reza Kiamanesh, and Abdolrahim Naveh Ebrahim (2011). Emotional Intelligence and Organisational Commitment: Testing the Mediatory Role of Occupational Stress and Job Satisfaction. Procedia - Social and Behavioral Sciences, Volume 29, 2011, Pages 1965-1976. The 2nd International Conference on Education and Educational Psychology 2011

Shann, M.H. (1998). Professional Commitment and Satisfaction among Teachers in Urban Middle Schools. Journal of Educational Research, 92, 67-73.

Stasz, C. and Wright, S. (2004). Emerging Policy for Vocational Learning in England. Will it Lead to a Better System? London: Learning and Skills Research Centre. dihttp:/www.voced.edu.au/content/ngv36805.

Sharifah Shafie, Suhaida Abdul Kadir\& Soaib Asimiran (2013). Beban Tugas Guru Kemahiran Hidup Bersepadu: Isu dan Cadangan, at 3rd Regional Conference on Educational Leadership and Management (RCELAM) 2013 on 19-21 November 2013 at Institut Aminuddin Baki, Genting Highlands, Malaysia.

Sy, T., Tram, S., and O’Hara, L. A. (2006). Relation of Employee and Manager Emotional Intelligence to Job Satisfaction and Performance. Journal of Vocational Behavior, 68, 461-473.

Spector, P.E. (1985). Measurement of Human Service Staff Satisfaction: Development of the Job Satisfaction Survey. American Journal of Community Psychology, 13(6), 693-713.

Spector, P. (1997). Job Satisfaction: Application, Assessment, Causes and Consequences. California: Sage.

Sidek Mohd Noah dan Mardiana Muhamad (1999). Kepuasan Bekerja di Kalangan Pegawai Tadbir Universiti Putra Malaysia, Serdang Selangor. Pertanika Jurnal of Social Sciences and Humanities. 7(1): 59-70

Tara Yost Bane (2006). Job Satisfaction Among Professional Middle School Counselors in Virginia. Doctor of Philosophy, Faculty of the Virginia Polytechnic Institute and State University.

Tabachnick, B. G., \& Fidell, L. S. (2007). Using Multivariate Statistics (5th ed.). Upper Saddle River, NJ: Pearson Allyn \& Bacon

Williams, L. J., and Hazer, J. T. (1986). Antecedents and Consequences of Satisfaction and Commitment in Turnover Models: A Reanalysis Using Latent Variable Structural Equation Methods. Journal of Applied Psychology, 71(2), 219231.

Yang F. H. and Chang C. C (2007). Emotional Labour, Job Satisfaction and Organisational Commitment amongst Clinical Nurses: A Questionnaire Survey. International Journal of Nursing Studies, 45 Pages 879-887.

Zainudin Awang (2012). Structural Equation Modelling Using AMOS Graphic. Shah Alam : UiTM Press.

Zainudin Awang (2015). Structural Equation Modelling Using AMOS Graphic. Shah Alam : UiTM Press. 